\title{
Feeding preferences in aquatic invertebrates associated to Egeria densa in a tropical high-mountain lake
}

\author{
Adriana Pedroza-Ramos ${ }^{* 1}$, Cesar E. Tamaris-Turizo ${ }^{2} \&$ Nelson Aranguren-Riaño ${ }^{1}$ \\ 1. Unidad de Ecología en Sistemas Acuáticos - UDESA, Universidad Pedagógica y Tecnológica de Colombia, Avenida \\ Central del Norte 39-15, Tunja, Boyacá, Colombia adrixipe@gmail.com \\ 2. Grupo de Investigación en Biodiversidad y Ecología Aplicada, Universidad del Magdalena, Carrera 32 No. 22 - 08, \\ Santa Marta, Colombia; ctamaris@unimagdalena.edu.co
}

\section{Received 07-X-2019. Corrected 07-VIII-2020. Accepted 31-VIII-2020.}

\begin{abstract}
Introduction: The benthic fauna of the littoral zone in lakes is important in transferring energy to other trophic levels, habitat coupling, and helping to keep habitat stability. The study of this type of interactions in lentic systems is priority, since functional aspects about biological communities are unknown. Objective: Describing the trophic relations of aquatic invertebrates of the littoral zone in a tropical high mountain lake by characterizing gut content and stable isotope analysis of $\delta^{13} \mathrm{C}$ and $\delta^{15} \mathrm{~N}$. Methods: Samples of benthic invertebrates were collected in the littoral zone of the Lago de Tota where Egeria densa was present using a handheld net method. Samples were processed in the laboratory, organisms were identified, counted and weighed. Gut contents and $\delta^{13} \mathrm{C}$ and $\delta^{15} \mathrm{~N}$ stable isotopes analysis were performed as well. Results: Records of the trophic relations of aquatic invertebrates, which live in the littoral in high mountain lentic ecosystem in the Neotropics are shown. The analysis of gut contents distinguished seven food items, microphytes and MOPF were the most frequent, and through the stable isotopes analysis $\left(\delta^{15} \mathrm{~N}\right)$ we identified four trophic levels, among resources (macrophytes and POM), and consumers (detritivores, herbivores, and predators). The two upper trophic levels concentrated greater diversity and biomass. Conclusion: Most of the organisms studied were linked to omnivorous habits, evidenced in a wide spectrum of food items in their diet. The $\delta^{15} \mathrm{~N}$ values show an enrichment, which occurs due to the effects of the tendency towards eutrophication of the system or due to unknown values of protozoa and bacteria that plays a fundamental role in the diet of these organisms, besides the $\delta^{13} \mathrm{C}$ values reported in organisms consumes, allows us to suggest an affinity with native resources of the littoral zone.
\end{abstract}

Key words: Lago de Tota; stable isotopes; gut contents; aquatic invertebrates; Neotropic.

Pedroza-Ramos, A., Tamaris-Turizo, C.E., \& Aranguren-Riaño, N. (2020). Feeding preferences in aquatic invertebrates associated to Egeria densa in a tropical high-mountain lake. Revista de Biología Tropical, 68(Suppl. 2), S92-S103.

Important processes happen in the littoral zone of lakes, impacting its function (Schindler et al., 1996). The coupling of matter and energy flows between habitats is largely determined by the activity of organisms and productivity (Schindler \& Scheuerell, 2002; Vanni, 2002). Thus, associated benthic fauna takes part in fractionating and transferring energy to other lake compartments. In addition, differentiation in benthic fauna trophic features, such as shredders, filterers, collectors-gatherers, scrapers, predators, have important impacts on the dynamics of matter and energy transfer through food web (Gillooly, Allen, \& Brown, 2006), and at the same time affects the expression of biological diversity and the degree of community stability (Diehl, 2014).

This trophic structure constitutes a fundamental characteristic of ecosystems since it allows knowing the links and the type 
of relationship among the organisms that compose it (Leibold, Chase, Shurin, \& Downing, 1997; Tilman et al., 1997). Studying feeding strategies allow us to infer about evolutionary convergences, performance, functional incidence, and biochemical differences in the mobilized resources (Merrit, Cummins, \& Berg, 2008). Most studies involving trophic interactions in aquatic invertebrates have been conducted in temperate zones (Heino, 2008; Merritt, Cummins, \& Berg, 2017), while for the tropical region this issue has been poorly addressed in specially for lentic ecosystems (Echelpoel et al., 2018; Rivera Usme, Pinilla Agudelo, \& Camacho Pinzón, 2013). Therefore, it is necessary to increase efforts to build models that allow us to understand functional aspects in addition to structural ones (Tomanova, Goitia, \& Helešic, 2006). In this way, the implications of these processes on the community and the dynamics of the lakes can be understood more objectively.

The methodology used to assign feeding habits and the trophic level of benthic organisms is complex due to the great variety of sources available as energy and its variability in space and time (Peterson, 1999). In addition, detritus, abundant in the littoral, is a heterogeneous resource with great incidence in the structure of the food web (Moore et al., 2004).

Most studies that involve trophic aspects focus on a traditional approach, i.e. gut content analysis, a technique that provides information on food items and their dimensions, as well as the specificity degree within the diet spectrum of each organism (Hyslop, 1980; RosiMarshall, Wellard, Hall, and Vallis, 2016). We can use part of this information to infer trophic guilds, as structural criteria, focuses on a group of species that share similar resources such exploited in a similar way in a competitive context (Blondel, 2003). Other approach and very popular in studies of aquatic macroinvertebrates are functional feeding groups (FFG), a combination of data on morpho-behavioral mechanisms and adaptations (food gathering apparatus, food type, etc.), reflecting the functional role of organisms in their ecosystems (Cummins, 1973; Merritt, Cummins, \& Berg, 2008). The difference between these approaches that seem synonymous lies in the guilds only refers to resource acquisition and functional groups embrace a wide range of ecosystem process, both without regard to a specific taxonomic determination (Blondel, 2003; Ramírez \& Gutiérrez-Fonseca, 2014).

Another approach used to study trophic relationships and its functional implications is through the assimilation of resources by means of the detection of the variation in the ratio of stable isotopes ratios of $\delta^{13} \mathrm{C}$ and $\delta^{15} \mathrm{~N}$ allow us to know attributes such as sources of energy, the degree of omnivorous taxa, the percentage of consumption and the trophic position it occupies within a food web (Carvalho, Brauns, \& Boe, 2014; Peterson \& Fry, 1987; Post, 2002). Therefore, the use of this tool becomes relevant if it takes into account that trophic niches can change between habitats, seasons, and even throughout organisms development. This is especially true in Neotropical taxa, it has been shown that they have great flexibility in life histories as an adaptation to the fluctuating conditions in the environment (Dangles, 2002; Tomanova et al., 2006), including trophic plasticity (Hurtado-Borrero, Tamaris-Turizo, López-Rodríguez, \& Tierno de Figueroa, 2018; Tamaris-Turizo, Pinilla-A, \& Muñoz, 2018).

Thus, the allocation of the food items involved in the diet of benthic organisms is sometimes inaccurate and does not reflect all integration of these organisms into the food web and the flow of matter from the system. This study aims to describe the trophic relations of aquatic invertebrates in the littoral zone of a tropical high mountain lake by characterizing gut contents and addition stable isotopes analysis of $\delta^{13} \mathrm{C}$ and $\delta^{15} \mathrm{~N}$, which allows to construct a conceptual model of a food web that incorporates a variety of possible interactions in the benthic fauna associated with the littoral zone in a tropical lake. 


\section{MATERIALS AND METHODS}

Study site: Lago de Tota is located between $5^{\circ} 28^{\prime}-5^{\circ} 39^{\prime} \mathrm{N} \& 72^{\circ} 51^{\prime}-73^{\circ} 0^{\prime} \mathrm{W}$ at 3015 $\mathrm{m}$ a.s.1., in the department of Boyacá, Colombia (Fig. 1). Lago de Tota has a maximum depth of $60 \mathrm{~m}$, an area of $60 \mathrm{~km}^{2}$ and an average multiyear temperature of $11^{\circ} \mathrm{C}$ (Cordero, Ruiz, \& Vargas, 2005). It is considered an ecosystem with high ecological importance because it hosts a great diversity of aquatic organisms that includes more than 105 species among phytoplankton, zoobenthos and zooplankton, including endemic species such as the copepods Metacyclops leptopus totaenis, Trococyclops prasinus altoandinus and the cladoceran Eurycercus norandinus (Pedroza-Ramos \& Rozo -Suárez, 2017). In addition, it also has species that are priority in terms of conservation such as spotted tingua (Porphyriops melanops bogotensis) categorized as: Endangered (EN) and the captain of the savanna (Eremophilus mutisii) as: Vulnerable (VU) (Ministerio de Ambiente y Desarrollo Sostenible, 2018).

Despite being considered strategic in ecological and also economic terms due to the great variety of ecosystem services it provides to the region, being a source of irrigation and supply for a population of more than 200000 people (Cañón \& Valdes, 2011), for years Lago de Tota has been subdued due to intensive cultivation of green onion (Allium fistulosum), sewage discharge and grow of rainbow trout (Oncorhynchus mykiss) in floating cages.

Sample collection: Two sampling campaigns were done in the littoral zone of Lago de Tota in 2013, where four sites with abundant development of Egeria densa were selected (Fig. 1). At each point, aquatic invertebrates were collected using a $50 \mathrm{~cm}$ diameter hand net with a $3 \mathrm{~mm}$ mesh, extracting $300 \mathrm{~g}$ of live vegetation (E. dense), which were stored in airtight bags. At each site, three replicates were,

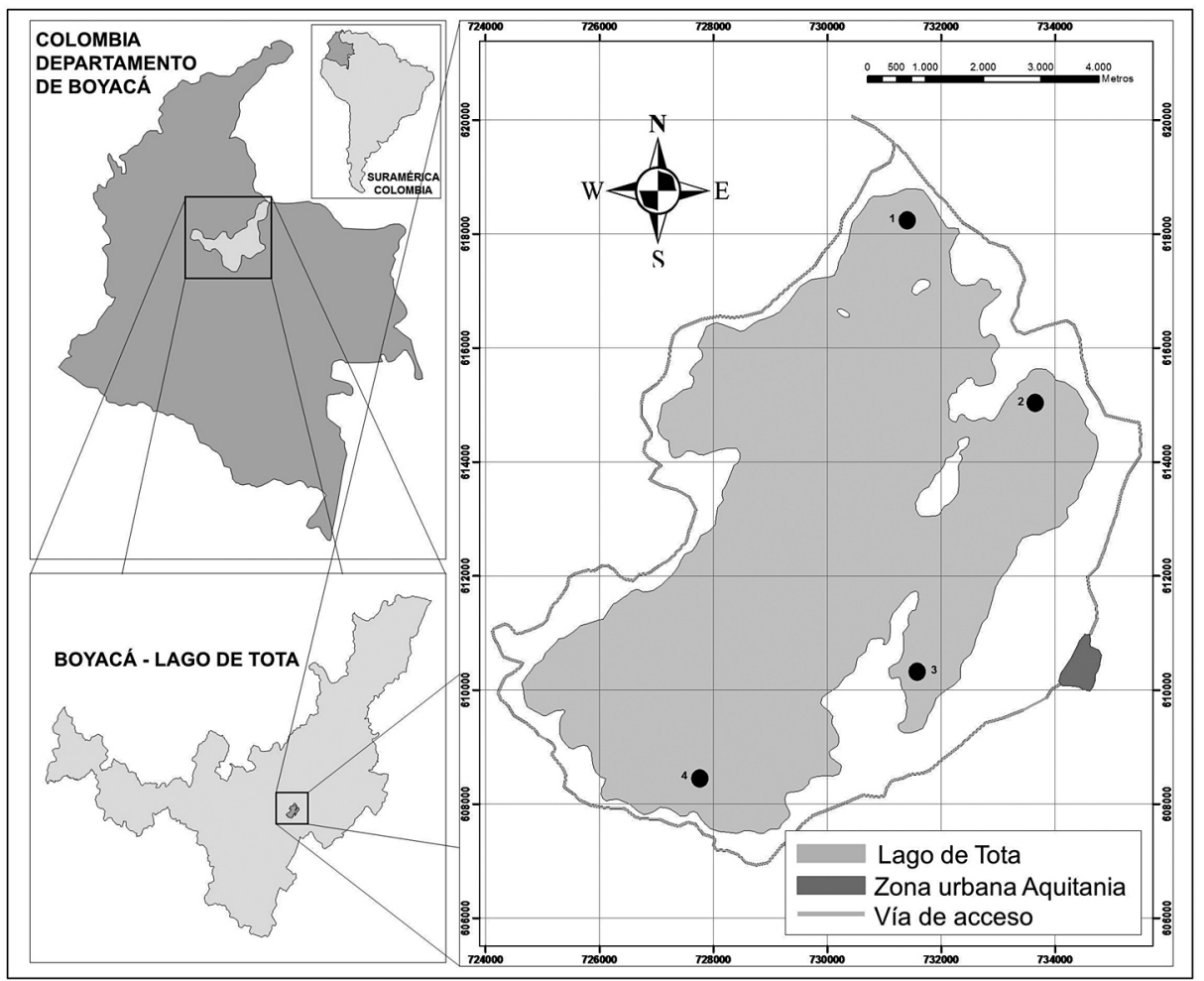

Fig. 1. Lago de Tota and location of sampling sites (1-Llano Alarcón, 2-Pispesca, 3-La Custodia, 4-Playa Blanca). 
for a total of 12 samples in each campaign. The material was washed carefully on a sieve with a $250 \mu \mathrm{m}$ mesh to remove excess sediment and fine material. The organisms were deposited in labeled bottles and then preserved with $70 \%$ ethanol for later identification. An additional sample was taken following the same methodology described above, with the difference that it was not preserved, it was frozen for further isotope processing.

Particulate organic matter (POM) samples were taken with a Van Dorn bottle (2.2L), from which a known amount of water was filtered through $0.47 \mu \mathrm{m}$ Advantec GF-75 glass fiber filters, previously burned in a muffle at $450{ }^{\circ} \mathrm{C}$ for 2 hours to avoid organic contamination (Konohira \& Yoshioka, 2005). At each point, we measured environmental parameters including water temperature, dissolved oxygen, oxygen saturation percentage (YSI 55-12FT oximeter), electrical conductivity (YSI 85 conductivity meter), $\mathrm{pH}$ (portable Schott $\mathrm{pH}$ meter) and Secchi disk transparency (Table 1).

Identification of organisms: The collected material was identified to the highest taxonomic resolution possible, using taxonomic keys and specialized bibliography such as Pennak (1989); Brinkhurst \& Marchese (1991); Hans (1988); FlöBner (2000); Meisch (2000); Merrit et al., (2008); Domínguez \& Fernández (2009); Ramírez (2010).

Biomass: A direct measurement of the biomass was carried out by the dry weight method (Rodrigues-Capítulo, Muñoz, Bonada, Gaudes,
\& Tomanova, 2009) for which a known number of organisms of the same morphospecies were separated, these were deposited in previously weighed aluminum boxes, and dried in a Memmert UNB-400 oven at $70{ }^{\circ} \mathrm{C}$ until constant weight. The dry weight value was divided by the total number of organisms to obtain the average weight of each individual, the final biomass per taxon is expressed in milligrams of organisms per gram of macrophyte (Table 2).

Gut contents: We extracted the digestive tracts of a minimum of five individuals per taxon. This material was deposited on a slide with glycerin (semi-permanent mounting), which was identified in a Nikon e200 optical microscope in 400 magnifications. The proportion of the relative area of each food item was determined visually by dividing the observation field by 4 in order to calculate the occupation area of the items found. In total 20 fields were observed that were randomly selected within the assembly. For the allocation of food items, the particle type and size were taken into account, in total seven categories were recognized as follows: coarse particulate organic matter $(\mathrm{CPOM},>1 \mathrm{~mm})$, fine particulate organic matter (FPOM, $<1 \mathrm{~mm}$ ), microphytes $(\mathrm{MiPH})$, macrophytes $(\mathrm{MaPH})$, macroinvertebrates (MaIn), microinvertebrates (MiIn), and fungi (FUNGI) (Tomanova et al ., 2006; Chará-Serna, Chará, Zúñiga, Pearson, \& Boyero, 2012).

Stable isotopes: We followed the protocol established by Stable Isotope Facility

TABLE 1

Average and standard deviation of the physical and chemical variables measured at each sampling sites in Lago de Tota

\begin{tabular}{lcccc}
\multicolumn{1}{c}{ Variables } & & \multicolumn{2}{c}{ Site } & La Custodia \\
$\mathrm{pH}$ & Pispesca & Llano Alarcon & Playa Blanca \\
Temperature $\left({ }^{\circ} \mathrm{C}\right)$ & $8.60 \pm 0.46$ & $8.68 \pm 0.49$ & $8.30 \pm 0.23$ \\
Conductivity $(\mu \mathrm{S} / \mathrm{cm})$ & $17.18 \pm 0.89$ & $17.08 \pm 1.09$ & $16.73 \pm 0.69$ \\
Secchi Disk Transparency $(\mathrm{m})$ & $87.28 \pm 0.94$ & $83.85 \pm 1.44$ & $84.47 \pm 1.51$ & $82.80 \pm 2.05$ \\
Oxygen saturation $(\%)$ & $0.70 \pm 0.84$ & $1.83 \pm 1.14$ & $2.31 \pm 1.64$ & $2.62 \pm 1.36$ \\
Oxygen concentration $(\mathrm{mg} / \mathrm{L})$ & $68.95 \pm 9.84$ & $66.68 \pm 17.47$ & $58.37 \pm 11.52$ & $7.52 \pm 0.99$ \\
\hline
\end{tabular}


TABLE 2

Taxonomic, biomass and trophic data of aquatic invertebrates associated with E. densa in Lago de Tota

\begin{tabular}{|c|c|c|c|c|c|c|}
\hline Trophic interaction & Order & Family & Genus/Species & $\begin{array}{c}\text { Total } \\
\text { Biomass } \\
(\mathrm{mg} / \mathrm{g})\end{array}$ & $\delta^{13} \mathrm{C}$ & $\delta^{15} \mathrm{~N}$ \\
\hline $\begin{array}{l}\text { Resource } \\
\text { Macrophytes } n=28\end{array}$ & & & & & $-19.11 \pm 2.44$ & $15.24 \pm 3.09$ \\
\hline $\begin{array}{l}\text { Resource } \\
\text { POM } n=12\end{array}$ & & & & & $-23.12 \pm 1.75$ & $13.07 \pm 2.41$ \\
\hline Predator & Tricladida & Dugesiidae & Girardia sp. & 0.0041 & -22.23 & 23.49 \\
\hline Predator & Rhynchobdellida & Glossiphoniidae & Helobdella sp. & 0.0051 & -15.66 & 22.40 \\
\hline Herbivore & & Ancylidae & Ferrissia sp. & 0.0059 & -17.67 & 19.37 \\
\hline Herbivore & Gastropoda & Physidae & Physella sp. & 0.1229 & -15.51 & 21.17 \\
\hline Herbivore & (Class) & Planorbidae & Planorbis sp. & 0.0015 & $\begin{array}{l}-12.82 \\
-14.45\end{array}$ & $\begin{array}{l}19.38 \\
19.35\end{array}$ \\
\hline Detritivore & Amphipoda & Hyalellidae & Hyalella paramoensis & 0.0158 & $\begin{array}{l}-17.29 \\
-18.56\end{array}$ & $\begin{array}{l}17.90 \\
15.57\end{array}$ \\
\hline Predator & Cyclopoida & Cyclopidae & Macrocyclops albidus & 0.0020 & -9.74 & 19.35 \\
\hline Herbivore & Podocopida & Cyprididae & Cypridopsis vidua & 0.0058 & $\begin{array}{l}-6.49 \\
-9.84\end{array}$ & $\begin{array}{l}20.97 \\
21.76\end{array}$ \\
\hline Detritivore & Sarcoptiformes & Hydrozetidae & Hydrozetes cf. dimorphus & 0.0098 & -15.92 & 16.38 \\
\hline Predator & & Aeshnidae & Coryphaeschna sp. & 1.4868 & -15.66 & 21.69 \\
\hline Predator & Odonata & Coenagrionidae & Ischnura hastata & 0.1181 & $\begin{array}{l}-14.59 \\
-18.72\end{array}$ & $\begin{array}{l}21.57 \\
20.29\end{array}$ \\
\hline Predator & Hemiptera & Corixidae & Neosigara sp. & 0.0127 & -11.05 & 19.34 \\
\hline Predator & Coleoptera & Gyrinidae & Gyrinus sp. & 0.0027 & $\begin{array}{l}-8.50 \\
-9.16\end{array}$ & $\begin{array}{l}20.67 \\
19.77\end{array}$ \\
\hline Herbivore & Trichoptera & Hydroptilidae & Oxyethira sp. & 0.0102 & -12.23 & 18.91 \\
\hline Herbivore & Diptera & Chironomidae & Dicrotendipes sp. & 0.0833 & $\begin{array}{l}-16.99 \\
-16.08\end{array}$ & $\begin{array}{l}20.16 \\
19.84\end{array}$ \\
\hline Predator & & & Ablabesmyia sp. & 0.0063 & -15.93 & 20.68 \\
\hline
\end{tabular}

UC-Davis. Organisms (without preserving). POM and macrophytes were dried in an oven at $60^{\circ} \mathrm{C}$ for $12 \mathrm{~h}$, or until the sample was considered dry. Subsequently, each one was weighed to target weight for each material using a Boeco BAS 31 plus analytical balance $( \pm 0.1 \mathrm{mg})$ and then packed in tin $(\mathrm{Sn})$ capsules. The leaves were included for macrophytes, the central part of the filter that had a higher concentration of material was included for POM, and only the tissue was included for invertebrates, in a case that organisms were lightweight, we put some individuals in the same capsule. Then, they were stored in sterile polystyrene trays (one for each type of material) which were closed using silicone lids to prevent material loss and moisture. These samples were processed using an elementary analyzer PDZ Europa ANCAGLS and GmbH, Hanau, Germany, both with an interface to mass spectrophotometer with 20-20 isotope ratio, where the proportions of $\delta^{13} \mathrm{C}$ and $\delta^{15} \mathrm{~N}$ were determined, using Agency standards Atomic Energy International (IAEA) of carbonated rock from Pee Dee Belemnite (PDB) and atmospheric nitrogen, respectively (Muñoz et al., 2009).

The abundances of isotopic signals were expressed by the equation:

$$
\delta \mathrm{X}=[(\text { Rsample / Rstandard })-1] * 1000(\%)
$$

Where $\mathrm{X}={ }^{13} \mathrm{C}$ or ${ }^{15} \mathrm{~N}$ and $\mathrm{R}=$ is the ratio between ${ }^{13} \mathrm{C}:{ }^{12} \mathrm{C}$ and ${ }^{15} \mathrm{~N}:{ }^{14} \mathrm{~N}$, respectively. 
Analysis of data: To establish the affinity of the food items with the different taxa, a network graph was made in RStudio with the "bipartite" package (Dormann, Fruend, \& Gruber, 2015), which allows the integration of the taxa with the weight of the resources.

The Bayesian model of Stable Isotope Analysis in $\mathrm{R}$ (Parnell, Inger, Bearhop, \& Jackson, 2010; Phillips et al., 2014) was performed to quantify the potential contribution of carbon and nitrogen from POM and macrophytes, respect to carbon assimilated by trophic guilds as detritivores, herbivores and predators (Table 2). Also, the contribution of the guild's herbivores and detritivores was evaluated on predator organisms. We used the isotopic fractionation in the mixture's models, tests were performed in SIAR using low $\delta^{15} \mathrm{~N}$ values $(2.54 \pm 1.0 \%$; Vanderklift and Ponsard 2003) fractionation; for the $\delta^{13} \mathrm{C}$ a fractionation of $0.4 \pm 1.3 \%$ was used (Post 2002). The SIAR models is fit via Markov Chain Monte Carlo (MCMC) were run 500000 interactions and burning 50 000, using Dirichlet prior probability distribution (siarsolomemcv4 command).

\section{RESULTS}

A total 112866 organisms belonging to eight classes, 16 orders, 23 families and 25 genera were collected. Odonata order (Coryphaeschna sp. and Ischnura hastata), Chironomidae family (Dicrotendipes sp.), and the Gastropoda class (Physella sp.) had the greatest biomass. According to the gut content, these groups include predators and herbivores,

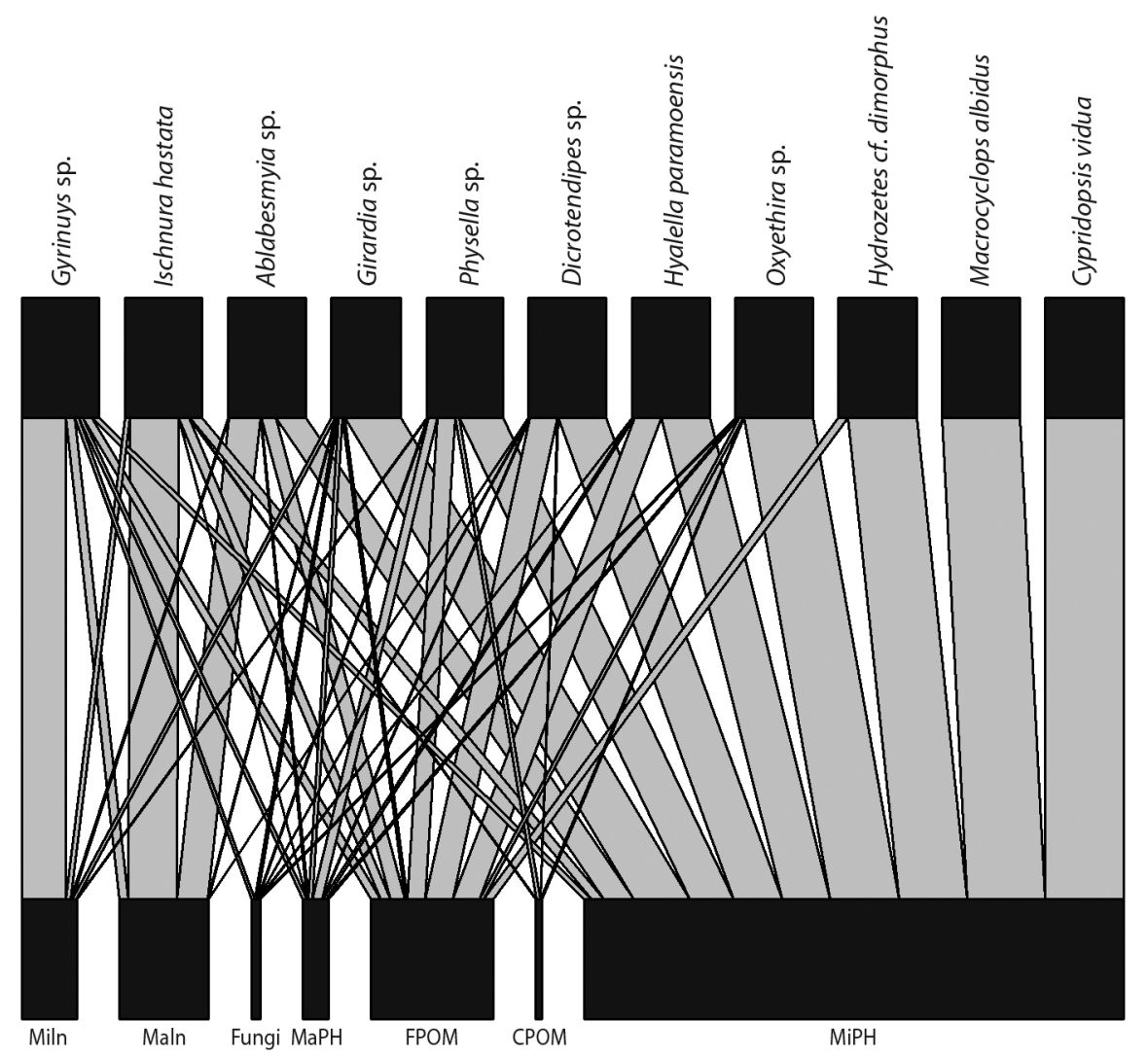

Fig. 2. Association between food resources and invertebrates of the littoral zone of Lago de Tota. Microinvertebrates (MiIn), macroinvertebrates (MaIn), fungi (Fungi), macrophytes (MaPH), fine particulate organic matter (FPOM), coarse particulate organic matter (CPOM) and microphytes $(\mathrm{MiPH})$. The thickness of the line indicates the proportion of use of the resource by the organisms. 
respectively. The organisms with the lowest biomass were the cladocerans (Simochephalus sp., Eurycercus norandinus, Macrothrix sp., Grabtoleberis sp. and Alonella sp.), the oligochaetes (Nais sp.), and the mites (Trimalaconothrus sp.). The copepods (Harpactidoida), the mites (Halacaridae), and the dipterans (Hemerodromia sp., Chelifera sp.) were scarce in the samples. From these organisms with low representativeness, it was not possible to obtain trophic data, the information of the other taxa are in Table 2.

The interaction analysis performed from the gut contents data for 11 taxa (Fig. 2) shows that microphytes $(\mathrm{MiPH})$ constitute the most frequent resource in the aquatic invertebrate community, registered for all organisms in different proportions, following by fine particulate organic matter (FPOM), in contrast to other items such as coarse particulate organic matter (CPOM), macrophytes $(\mathrm{MaPH})$, and fungi (FUNGI). Gut contents results showed that the specialists corresponded to $18.2 \%$, this group refers to organisms that make use of a single type of resource, and in this case $\mathrm{MiPH}$, and the generalists were $82 \%$ who used multiple types of resources (i.e., classical view).

Considering that an enrichment $\delta^{15} \mathrm{~N}$ of $2.54 \pm 1.0 \%$ will be interpreted as a trophic level, the stable isotope analyzes (Fig. 3), showed detritivores as the first-order consumer with the lower values of $\delta^{15} \mathrm{~N}(18.22 \pm 2.02 \%)$, and with high variability. We found herbivores in the second order consumer with $\delta^{15} \mathrm{~N}(20.1$ $\pm 0.98 \%$ ). The predators are in in-between second and third-order consumers (higher level) as the most enriched $\delta^{15} \mathrm{~N}(21.28 \pm 1.37 \%$ ), considered as top-predators, Girardia sp., Helobdella sp., Coryphaeschna sp. here, at the same time, this guild showed high variability of $\delta^{13} \mathrm{C}$ (-14.78 $\pm 4.46 \%$ ). The zoobenthos Cypridopsis vidua and Macrocyclops albidus, the beattle Gyrinus sp., and the amphipod Hyalella paramoensis showed the lowers value of $\delta^{13} \mathrm{C}$.

The bayesian model of stable isotope estimated that macrophytes contributed $94 \%$ of herbivores and $47 \%$ of detritivores, as long as POM contributed $6.4 \%$ in the diet of predators, $5.7 \%$ of herbivores and $53 \%$ of detritivores. On the other hand, detritivores contributed $72 \%$

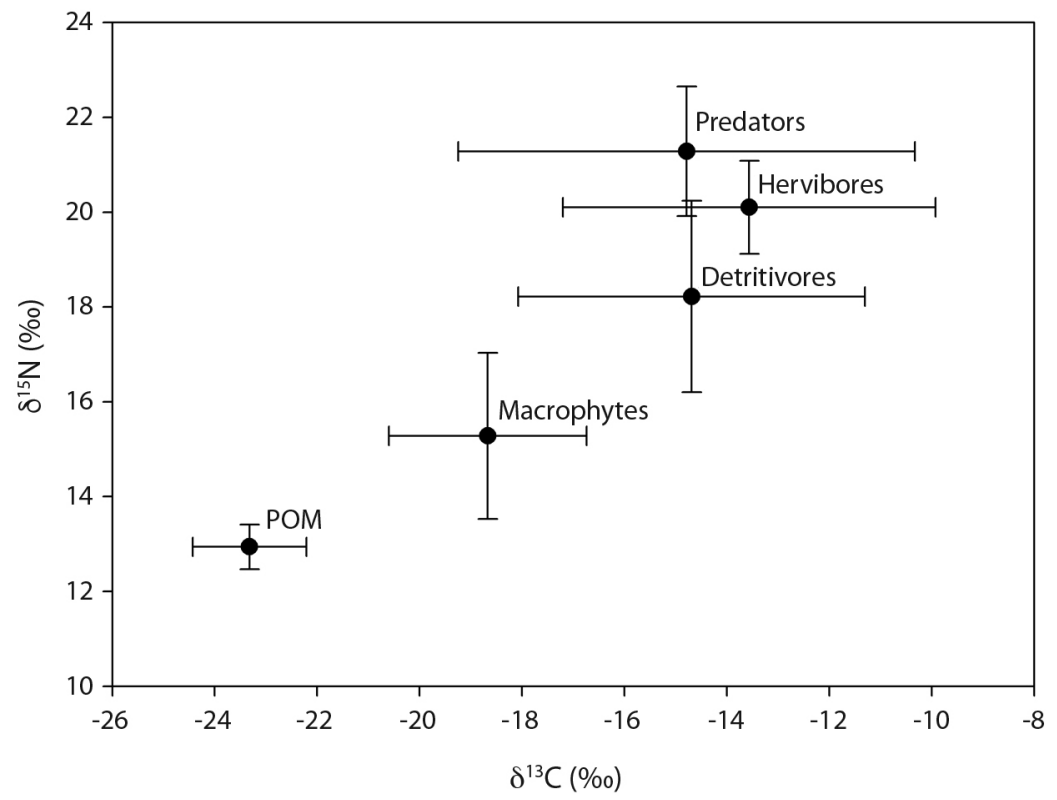

Fig. 3. Biplot of signal values of $\delta^{13} \mathrm{C}$ and $\delta^{15} \mathrm{~N}$ for resources and consumers in the littoral zone of Lago de Tota. Points are mean values with bars representing standard deviation. Basal resources are POM and Macrophytes, and consumers are detritivores, herbivores and predators. 
of dragonflies and beetles, while herbivores contributed $70 \%$ of Glossiphoniidae and Dugesiidae (70\%).

\section{DISCUSSION}

Analysis of stable isotopes and gut contents of invertebrates from the littoral zone of Lago de Tota, showed that omnivory is the most frequent dietary habit, considered to be typical of these taxa, at least in the early instars (Merritt, Cummins, \& Berg, 2008). In the gut content analysis, we found that $82 \%$ of the organisms consumed more than one food item and from those $55 \%$ use ate items from a different trophic level. Nevertheless, $\delta^{15} \mathrm{~N}$ analysis showed that most of the organisms are categorized between second and third-order consumers, thus supporting the hypothesis proposed by Tomanova et al., (2006), where omnivory is the most common characteristic, being a possible adaptive response to the heterogeneity and temporal variability in resources supply, e.g. Dicrotendipes (Chironomidae) are usually known as collector-gatherers with a preference towards detritus as has been recorder by Ruiz, Rivera-Rondon, \& Ovalle (2018), who also registered it as an "algivore" but in a little percent, in this study, prefers algae rather than detritus, evidencing the ability of organisms to adapt to local conditions, where the great majority of chironomids species are considered as opportunistic (Henriques-Oliveira, Nessimian, \& Dorvillé, 2003).

Regarding food sources, the gut content analysis showed that fine particulate organic matter (FPOM) is considered a resource of great importance for invertebrates in freshwater ecosystems, at least in running waters, due to its high abundance, availability and number of associated taxa, (Chará-Serna, Chará, Zúñiga, Pearson, \& Boyero, 2012; GranadosMartínez, Zúñiga-Céspedes, \& Acuña-Vargas, 2016; Tamaris-Turizo et al., 2018; Tomanova et al., 2006). However, in this study, it was not the most frequent resource, even in relation to other lentic systems, where organisms, are mostly shredders and filterers; and even quoted by Johnson, Goedkoop, and Sandin (2004) who found that the retention and processing of organic matter in the littoral zone of the lakes is high.

Our results of gut contents suggest that microphytes (MiPH), which include algae from Periphytic and planktonic origins, are important resources for aquatic invertebrates on the littoral of Lago de Tota. This resource showed high interaction with taxa such as Cypridopsis vidua, Hydrozetes cf. dimorphus, Hyalella paramoensis and Oxyethira sp., supporting traditional postulates (Elton, 1927), which suggests that trophic relationships in lakes are strongly linked to the autochthonous carbon, which is derived from the photosynthetic production of the system itself.

At the same time, recent studies show that heterotrophic pathways can become more common and important than previously thought, since the two sources of organic matter are indispensable elements in energy transfer within the lakes (Jansson, Persson, De Roos, Jones, \& Tranvik, 2007; Mello Brandão et al., 2018). These could be caused by the consumption of microbial loop by macroherbivores (Waichman, García-Dávila, Hardy, \& Robertson, 2002), the high values of $\delta^{15} \mathrm{~N}$ e.g. Physella sp. suggested that these organisms have a broad spectrum of diet, which could be associated with scrapers feeding habits (Cummins, Merritt, \& Andrade, 2005), or categorize them as facultative organisms including algae, protozoans, and even decaying animals in their diets (Brown, 1982; Chase, 2003). Furthermore, the high concentrations of nitrogen could be a result of agricultural practices carried out in the upper part of the basin for decades, then mainly showing enrichment in the littoral zone (Aranguren-Riaño et al., 2018), or maybe a contribution of microbial loop indirectly linked to energy flows in this area. For that reason, we have a tangle signal of $\delta^{15} \mathrm{~N}$ among herbivores and predators, suggesting a niche overlap in resource use among these organisms, it happens when the resource is abundant (Blondel, 2003).

Circulation of organic matter in lakes, is linked to its characteristic to have a tendency 
to eutrophication, with an increase higher than fivefold in planktonic algae during the last decade (Aranguren-Riaño et al., 2018). Algae can be a relevant component in the flow of matter and energy, even in the littoral zone. Planktonic algae, such as Staurastrum and Desmodesmus were the most common taxa found in gut contents, along with Achanthales, Navicula and Cymbellales associated with periphyton. These results corroborate those found by Hadwen \& Bunn (2005) who showed that despite the prevalence of allochthonous carbon from the basin and emerging macrophytes from the littoral zone, the phytoplankton is also a source of food for invertebrates in lakes (Solomon, Carpenter, Cole, \& Pace, 2008). On the other hand, we have some organisms of zoobenthos with low values of $\delta^{13} \mathrm{C}$ that are feeding other resources that were not evaluated here.

The $\delta^{15} \mathrm{~N}$ values placed Girardia sp., Helobdella sp., Coryphaeschna sp and Ischnura hastata, as predator organisms, thus confirming literature records (Young \& Ironmonger, 1980; Merrit et al., 2008) and previous studies in Lago de Tota (Pedroza-Ramos, Caraballo, \& Aranguren-Riaño, 2016). The $\delta^{15} \mathrm{~N}$ value allowed to identify the planarians, leeches and odonates as top-predators, showing importance in controlling population dynamics of a wide range of organisms (Stoks \& Córdoba-Aguila, 2012). According to the gut contents analysis, Odonata showed the widest spectrum of diet, the chironomids are an important fraction as prey and cannibalism as a positive feedback process, getting the highest biomass content in the community.

This study is one of the first records of trophic habits of aquatic invertebrates associated with the littoral zone in lentic ecosystems of high Neotropical mountains. The two techniques showed a more accurate reading of the trophic relationships of these organisms, showing a tendency towards omnivory, with a high preference for microphytes. In addition, the use of two techniques brought complementary information, each time the gut content analysis did not recognize the trophic levels of the food web, which was evident in the isotope analysis
(4 levels), however, the number of replicates for isotopes is insufficient and it is necessary to evaluate another possible source of resources to disentangle the trophic role of these organisms. Finally, it should be noted that the analysis of stable isotopes revealed the effect of eutrophication through the concentration of $\delta^{15} \mathrm{~N}$ values in both producers and consumers.

Ethical statement: authors declare that they all agree with this publication and made significant contributions; that there is no conflict of interest of any kind; and that we followed all pertinent ethical and legal procedures and requirements. All financial sources are fully and clearly stated in the acknowledgements section. A signed document has been filed in the journal archives.

\section{ACKNOWLEDGMENTS}

We thank Hamanda B Cavalheri for the most valuable review of the manuscript, and Jonathan Shurin for isotope laboratory tests. We are grateful to Marina Tagliaferro, Pablo Gutiérrez Fonseca, and two anonymous reviewers for useful comments and suggestions.

\section{RESUMEN}

Preferencias alimenticias de invertebrados acuáticos asociados a Egeria densa de un lago de alta montaña tropical. Introducción: La fauna béntica de la zona litoral de los lagos constituye un vínculo importante en el acoplamiento de hábitats, dinamizando los procesos de transferencia de materia y energía, y con ellos la estabilidad del sistema. El estudio de este tipo de interacciones en sistemas lénticos es prioritario, ya que existen vacíos de información sobre aspectos funcionales que involucran a las comunidades biológicas. Objetivo: Describir las relaciones tróficas de invertebrados acuáticos de la zona litoral de un lago de alta montaña tropical mediante caracterización de contenidos estomacales y análisis de isótopos estables de $\delta^{15} \mathrm{~N}$ y $\delta^{13} \mathrm{C}$. Métodos: Se colectaron muestras en la zona litoral del Lago de Tota, asociadas con la presencia de Egeria densa utilizando una red portátil. Las muestras se procesaron en el laboratorio donde los organismos se identificaron, contaron y pesaron. También se realizaron análisis de contenido estomacal e isótopos estables $\delta^{13} \mathrm{C}$ y $\delta^{15} \mathrm{~N}$. Resultados: Presentamos registros sobre hábitos tróficos de invertebrados acuáticos de litoral 
para ecosistemas lénticos de alta montaña del Neotrópico. El análisis de contenido estomacal permitió distinguir siete ítems alimenticios, donde los micrófitos y la MOPF fueron los recursos más frecuentes y el análisis de isótopos estables permitió identificar cuatro niveles tróficos, un nivel basal que hace referencia a los recursos (Macrófitos, MOP) y consumidores detritívoros, herbívoros y depredadores. Los dos niveles tróficos superiores concentraron mayor diversidad y biomasa. Conclusión: La mayor parte de los organismos estudiados fueron vinculados con hábitos omnívoros, evidenciado en un amplio espectro de ítems alimenticios en su dieta. Los valores de $\delta^{15} \mathrm{~N}$ muestran un enriqueciendo que puede deberse a la tendencia del lago hacia la eutroficación o por valores desconocidos de protozoos y bacterias que pueden estar jugando un rol fundamental en la dieta de estos organismos, adicionalmente los valores de $\delta^{13} \mathrm{C}$ reportados en los organismos consumidores nos permiten sugerir una afinidad hacia recursos propios de la región litoral.

Palabras clave: Lago de Tota; isótopos estables; contenidos estomacales; invertebrados acuáticos; Neotrópico.

\section{REFERENCES}

Aranguren-Riaño, N., Shurin, J. B., Pedroza-Ramos, A., Muñoz, C., López, R., \& Cely, O. (2018). Sources of nutrients behind recent eutrophication of Lago de Tota, a high mountain Andean lake. Aquatic Sciences, 80:39. https://doi.org/10.1007/s00027-018-0588-x.

Blondel, J. (2003). Guilds or functional groups: Does it matter? Oikos, 100(2), 223-231. https://doi. org/10.1034/j.1600-0706.2003.12152.x

Brinkhurst, R., \& Marchese, M. (1991). Guía para la identificación de oligoquetos acuáticos continentales de Sud y Centroamérica (2 ed). Asociación de Ciencias Naturales del Litoral.

Brown, K. (1982). Resource Overlap and Competition in Pond Snails: An Experimental Analysis. Ecology, 63(2), 412-422. https://doi.org//10.2307/1938959.

Cañón, J., \& Valdes, J. (2011). Assessing the influence of global climate and anthropogenic activities on the water balance of an Andean Lake. Journal of Water Resource and Protection, 3, 883-891. https://doi. org/10.4236/jwarp.2011.312098.

Chará-Serna, A. M., Chará, J. D., Zúñiga, M. del C., Pearson, R. G., \& Boyero, L. (2012). Diets of leaf litterassociated invertebrates in three tropical streams. Annales de Limnologie - International Journal of Limnology, 48(2), 139-144. https://doi.org/10.1051/ $\operatorname{limn} / 2012013$.

Chase, J. M. (2003). Experimental evidence for alternative stable equilibria in a benthic pond food web. Ecology Letters, 6, 733-741. https://doi. org/10.1046/j.1461-0248.2003.00482.x.

Cordero, R. D., Ruiz, J. E., \& Vargas, E. F. (2005). Spatial temporal determination of phosphorus concentration in Lake of Tota. Revista Colombiana de Química, 34(2), 211-218. Retrieved from http://www.scielo.org.co/scielo.php?pid=S012028042005000200010\&script=sci_arttext\&tlng=pt.

Cummins, K., Merritt, R., \& Andrade, P. (2005). The use of invertebrate functional groups to characterize ecosystem attributes in selected streams and rivers in south Brazil. Studies on Neotropical Fauna and Environment, 40(1), 69-89. https://doi. org//10.1080/01650520400025720.

Cummins, K. (1973). Trophic relations in aquatic insects. Annual Review of Entomology, 18(220), 183-206. https://doi.org/10.1146/annurev.en.18.010173.001151

Carvalho, A. P. C., Gücker, B., Brauns, M \& Boëchat, I. (2014). High variability in carbon and nitrogen isotopic discrimination of tropical freshwater invertebrates. Aquatic Sciences 77:307. https://doi.org/10.1007/ s00027-014-0388-x.

Dangles, O. (2002). Functional plasticity of benthic macroinvertebrates: implications for trophic dynamics in acid streams. Canadian Journal of Fisheries and Aquatic Sciences, 59(9), 1563-1573. https://doi. org/10.1139/f02-122.

Diehl, S. (2014). Direct and Indirect Effects of Omnivory in a Littoral Lake Community. Ecology, 76(6), 17271740. https://doi.org/10.2307/1940706.

Domínguez, E., \& Fernández, H. R. (Eds.). (2009). Macroinvertebrados bentónicos sudamericanos: Sistemática y biología (1 ra ed.). Tucumán: Fundación Miguel Lillo.

Dormann, C., Fruend, J., \& Gruber, B. (2015). Package"bipartite."

Echelpoel, W. Van, Eurie, M. A., Butsel, J. Van, Lock, K., Antonio, J., Dueñas, A., ... Goethals, P. L. M. (2018). Macroinvertebrate functional feeding group structure along an impacted tropical river: The Portoviejo River (Ecuador). Limnologica, 73(1), 12-19. https:// doi.org/10.1016/j.limno.2018.10.001.

Elton, C. (1927). Animal Ecology. New York: MacMillan.

FlöBner, D. (2000). Die Haplopoda und Cladocera (ohne Bosminidae) Mitteleuropas. Leiden: Backhuys Publishers.

Gillooly, J. F., Allen, A. P., \& Brown, J. H. (2006). Foodweb structure and dynamics: Reconciling alternative ecological currencies. In M. Pascual \& J. A. Dunne (Eds.), Ecological Networks (Santa Fe I, pp. 209220). New York: Oxfford University Press. 
Granados-Martínez, C., Zúñiga-Céspedes, B., \& AcuñaVargas, J. (2016). Diets and trophic guilds of aquatic insects in molino river, La Guajira, Colombia. Journal of Limnology, 75(1S), 144-150. https://doi. org/10.4081/jlimnol.2016.1396.

Hadwen, W. L., \& Bunn, S. E. (2005). Food web responses to low-level nutrient and ${ }^{15} \mathrm{~N}$-tracer additions in the littoral zone of an oligotrophic dune lake. Limnology and Oceanography. 50(4), 1096-1105. https://doi. org/10.4319/lo.2005.50.4.1096.

Hans, A. (1988). Hyalella paramoensis sp. n. aus dem Páramo de Chisacá (Anden) (Crustacea: Amphipoda:Talitroidea). Mitteilungen Aus Dem Hamburgischen Zoologischen Museum Und Institut, 85, 103-109.

Heino, J. (2008). Patterns of functional biodiversity and function - environment relationships in lake littoral macroinvertebrates. Limnology and Oceanography 53(4), 1446-1455. https://doi.org/10.4319/ lo.2008.53.4.1446.

Henriques-Oliveira, A. L., Nessimian, J. L., \& Dorvillé, L. F. (2003). Feeding habits of chironomid larvae (Insecta: Diptera) from a stream in the Floresta da Tijuca, Rio de Janeiro, Brazil. Brazilian Journal of Biology, 63(2), 269-281. https://doi.org/10.1590/ S1519-69842003000200012.

Hurtado-Borrero, Y. M., Tamaris-Turizo, C. E., LópezRodríguez, M. J., \& Tierno de Figueroa, M. J. (2018). Nymphal feeding habits of two Anacroneuria species (Plecoptera, Perlidae) from Sierra Nevada de Santa Marta, Colombia. Journal of Limnology, 78(1), 40-46. https://doi.org/10.4081/jlimnol.2018.1858.

Hyslop, E. J. (1980). Stomach contents analysis-a review of methods and their application. Fish Biol, 17, 411-429. https://doi.org//10.1111/j.1095-8649.1980. tb02775.x.

Jansson, M., Persson, L., De Roos, A., Jones, R., \& Tranvik, L. J. (2007). Terrestrial carbon and intraspecific size-variation shape lake ecosystems. Trends in Ecology and Evolution, 22(6), 316-322. https://doi. org/10.1016/j.tree.2007.02.015.

Johnson, R. K., Goedkoop, W., \& Sandin, L. (2004). Spatial scale and ecological relationships between the macroinvertebrate communities of stony habitats of streams and lakes. Freshwater Biology, 49(9), 1179-1194. https://doi.org/10.1111/j.1365-2427.2004.01262.x.

Konohira, E., \& Yoshioka, T. (2005). Dissolved organic carbon and nitrate concentrations in streams : a useful index indicating carbon and nitrogen availability in catchments. In T. Kohyama, 1 J. Canadel, D. Ojima, \& L. Pitelka (Eds.), Forest Ecosystems and Environments (Springer, Vol. 20, pp. 359-365). Tokyo. https://doi.org/10.1007/s11284-005-0051-z.
Leibold, M. A., Chase, J. M., Shurin, J. B., \& Downing, A. L. (1997). Species Turnover and the Regulation of Trophic Structure. Annual Review of Ecology and Systematics, 28, 467-494. https://doi.org//10.1146/ annurev.ecolsys.28.1.467.

Meisch, C. (2000). Freshwater Ostracoda of Western and Central Europe (Bd.8.Crust). Berlin: Spektrum Akademischer Verlag.

Mello Brandão, L., Brighenti, L., Staehr, P., Asmala, E., Massicotte, P., Rodrigues, F., ... Bezerra-Neto, J. (2018). Distinctive effects of allochthonous and autochthonous organic matter on CDOM spectra in a tropical lake. Biogeosciences, 15, 2931-2943. https:// doi.org//10.5194/bg-15-2931-2018.

Merrit, R. W., Cummins, K. W., \& Berg, M. B. (Eds.). (2008). An introduction to the aquatic insects of North America (4th ed.). Kendall Hunt Publishing Comapany.

Merritt, R., Cummins, K., \& Berg, M. (2017). Trophic Relationships of Macroinvertebrates. In F. Hauer \& A. Gary (Eds.), Methods in Stream Ecology (pp. 413433). Academic Press.

Ministerio de Ambiente y Desarrollo Sostenible. (2018). Lista de especies silvestres amenazadas de la diversidad biológica continental y marino-costera de Colombia - Resolución 1912 de 2017 expedida por el Ministerio de Ambiente y Desarrollo Sostenible. https://doi.org//10.15472/5an5tz

Moore, J. C., Berlow, E. L., Coleman, D. C., de Ruiter, P. C., Dong, Q., Hastings, A., ... Wall, D. J. (2004). Detritus, trophic dynamics and biodiversity. Ecology Letters, 7, 584-600. https://doi. org/10.1111/j.1461-0248.2004.00606.x.

Muñoz, I., Rodrigues-Capítulo, A., Camacho, A., Gonzáles, J. M., Romaní, A. M., \& Sabater, S. (2009). Flujo de energía en el ecosistema fluvial. Producción primaria y producción secundaria. In A. Elosegi \& S. Sabater (Eds.), Conceptos y técnicas en ecología fluvial (pp. 323-346). Fundación BBVA.

Parnell, A. C., Inger, R., Bearhop, S., \& Jackson, A. L. (2010). Source partitioning using stable isotopes: Coping with too much variation. PLoS ONE, 5(3), e9672. https://doi.org/10.1371/journal.pone.0009672.

Pedroza-Ramos, A., Caraballo, P., \& Aranguren-Riaño, N. (2016). Estructura trófica de los invertebrados acuáticos asociados a Egeria densa (Planch. 1849) en el Lago de Tota, (Boyacá-Colombia). Intropica, 11, 21-34. https://doi.org/10.21676/23897864.1858.

Pedroza-Ramos, A., \& Rozo-Suárez, S. (Eds.). (2017). Catálogo de la Biota Acuática del Lago de Tota (Boyacá, Colombia): Fitoplancton, Zooplancton y Zoobentos. Tunja: Editorial UPTC. 
Pennak, R. (1989). Fresh-Water invertebrates of the United States: Protozoa to Mollusca (3rd ed.). John Wiley \& Sons, INC.

Peterson, B. J. (1999). Stable isotopes as tracers of organic matter input and transfer in benthic food webs : A review. Acta Oecologia, 20(4), 479-487. https://doi. org/10.1016/S1146-609X(99)00120-4.

Peterson, B. J., \& Fry, B. (1987). Stable Isotopes in Ecosystem. Annual Review of Ecology and Systematics, 18, 293-320. https://doi.org/10.1146/annurev. es.18.110187.001453.

Phillips, D. L., Inger, R., Bearhop, S., Jackson, A. L., Moore, J. W., Parnell, A. C., ... Ward, E. J. (2014). Best practices for use of stable isotope mixing models in food-web studies. Canadian Journal of Zoology, 92(10), 823-835. https://doi.org/10.1139/ cjz-2014-0127.

Post, D. (2002). Using stable isotopes to estimate trophic position: models, methods, and assumptions. Ecology, 83(3), 703-718. https://doi. org//10.1890/0012-658(2002)083[0703:USITET]2.0 . $\mathrm{CO} ; 2$.

Ramírez, A. (2010). Odonata. Revista de Biología Tropical, 58(Suppl. 4), 97-136.

Ramírez, A., \& Gutiérrez-Fonseca, P. E. (2014). Functional feeding groups of aquatic insect families in Latin America: A critical analysis and review of existing literature. Revista de Biología Tropical, 62(2), 155-167. https://doi.org/10.15517/rbt.v62i0.15785.

Rivera Usme, J. J., Pinilla Agudelo, G., \& Camacho Pinzón, D. L. (2013). Macroinvertebrate Trophic Groups in an Andean Wetland of Colombia. Acta Biológica Colombiana, 18(2), 279-292. https://doi.org/http:// dx.doi.org/10.1590/1519-6984.10613.

Rodrigues-Capítulo, A., Muñoz, I., Bonada, N., Gaudes, A., \& Tomanova, S. (2009). La biota de los ríos: los invertebrados. In A. Elosegi \& S. Sabater (Eds.), Conceptos y técnicas en ecología fluvial (pp. 253270). Bilbao: Fundación BBVA.

Rosi-Marshall, E. J., Wellard, K., Hall Jr, R. O., \& Vallis, K. A. (2016). Methods for quantifying aquatic macroinvertebrate diets. Freshwater Science, 35(1), 229-236. https://doi.org/10.1086/684648.

Ruiz, Y., Rivera-Rondon, C. A., \& Ovalle, H. (2018). Feeding habits of chironomids (Diptera: Chironomidae) of Paramo Lakes, Chingaza, Colombia. Revista de Biologia Tropical, 66(1), 136-148. https://doi. org/10.15517/rbt.v66i1.28951.

Schindler, D. E., Carpenter, S. R., Kathryn, L. C., He, X., Hodgson, J. R., Kitchell, J. F., ...
Soranno, P. A. (1996). Food Web Structure and Littoral Zone Coupling to Pelagic Trophic Cascades. (G. A. Polis \& W. K.O., Eds.). Boston: Springer. https:// doi.org//10.1007/978-1-4615-7007-3_9.

Schindler, D. E., \& Scheuerell, M. D. (2002). Habitat Coupling in Lake Ecosystems. Oikos, 98(2), 177-189. https://doi.org/10.1034/j.1600-0706.2002.980201.x.

Solomon, C. T., Carpenter, S. R., Cole, J. J., \& Pace, M. L. (2008). Support of benthic invertebrates by detrital resources and current autochthonous primary production: results from a whole-lake ${ }^{13} \mathrm{C}$ addition. Freshwater Biology, 53, 42-54. https://doi. org/10.1111/j.1365-2427.2007.01866.x.

Stoks, R., \& Córdoba-Aguilar, A. (2012). Evolutionary Ecology of Odonata : A Complex Life Cycle Perspective. Annu. Rev. Entomol., 57, 249-265. https://doi. org/10.1146/annurev-ento-120710-100557.

Tamaris-Turizo, C. E., Pinilla-A, G. A., \& Muñoz, I. (2018). Trophic network of aquatic macroinvertebrates along an altitudinal gradient in a Neotropical mountain river. Revista Brasileira de Entomologia, 62(3), 180-187. https://doi.org//10.1016/j.rbe.2018.07.003.

Tilman, D., Knops, J., Wedin, D., Reich, P., Ritchie, M., \& Siemann, E. (1997). The Influence of Functional Diversity and Composition on Ecosystem Processes. Science, 277(5330), 1300-1302. https://doi. org/10.1126/science.277.5330.1300.

Tomanova, S., Goitia, E., \& Helešic, J. (2006). Trophic levels and functional feeding groups of macroinvertebrates in neotropical streams. Hydrobiologia, 556(1), 251-264. https://doi.org/10.1007/s10750-005-1255-5.

Vanderklift, M. A., \& Ponsard, S. (2003). Sources of variation in consumer-diet $\delta^{15} \mathrm{~N}$ enrichment: A metaanalysis. Oecologia, 136(2), 169-182. https://doi. org/10.1007/s00442-003-1270-z.

Vanni, M. J. (2002). Nutrient Cycling by Animals in Freshwater Ecosystems. Annual Review of Ecology and Systematics, 33(1), 341-370. https://doi.org/10.1146/ annurev.ecolsys.33.010802.150519.

Waichman, A. V, García-Dávila, C. R., Hardy, E. R., \& Robertson, B. A. (2002). Composição do Zooplâncton em diferentes ambientes do lago Camaleão, na ilha da Marchantaria, Amazonas, Brasil. Acta Amazonica, 32(2), 339-347. https://doi. org//10.1590/1809-43922002322347.

Young, J., \& Ironmonger, J. (1980). A laboratory study of the food of three species of leeches occuring in British Lakes. Hydrobiologia, 68, 209-215. https://doi. org//10.1007/BF00018828. 